Article

\title{
Study on the Optimization of the Industrial Structure in a Mining Economic Region: Taking Carbon Emissions as a Restriction
}

\section{$\mathrm{Li} \mathrm{Li}{ }^{1,3}$, Yalin Lei ${ }^{2,3, *}$, Lianrong Zhao ${ }^{2,3, *}$ and Xianhai $\mathrm{Li}^{2,3}$}

1 School of Public Policy and Management, Tsinghua University, Beijing 100084, China; E-Mail: lilyght@126.com

2 School of Humanities and Economic Management, China University of Geosciences, Beijing 100083, China; E-Mail: lixianhai@126.com

3 Key Laboratory of Carrying Capacity Assessment for Resource and Environment, Ministry of Land and Resources, Beijing 100083, China

* Author to whom correspondence should be addressed; E-Mails: leiyalin@cugb.edu.cn (Y.L.); zhaolr@cugb.edu.cn (L.Z.); Tel.: +86-10-8232-3525 (Y.L.); Fax: +86-10-8232-1006 (Y.L.).

Academic Editor: Mustafa Kumral

Received: 20 October 2014 / Accepted: 7 April 2015 / Published: 14 April 2015

\begin{abstract}
In the first decade of the 21st century, as a typical coal province and mining economic region, Shanxi province made a great contribution to the national economic construction and reform. At the same time, coal mining has caused serious damage to the ecological environment, excessive use of resources, the deterioration of the ecological environment and a decline in the sustainable development capacity. Overreliance on a resource-based economy leads to problems such as a poorly developed economy and a single industrial structure. In this context, Shanxi province has to take actions to transform its industrial structure into a low-carbon development model as soon as possible. This paper measures the values of the consumption coefficients of capital investments, electric power and $\mathrm{CO}_{2}$ emissions by establishing a Grey Model $(1,1)$ using the data from 2007 to 2011 and designing the optimization scheme of the three industrial structures from 2015 to 2020 by establishing a grey dynamic linear programming model for Shanxi province. The results show that the industrial structure in Shanxi province needs to be improved. It is revealed that the proportion of three industries in Shanxi province should change from 6:46:48 in 2015 to 6:41:54 in 2020. At the same time, among the seven largest sectors in terms of carbon emissions in the secondary industry, Shanxi government may continue to
\end{abstract}


promote the development of the coal-bed methane and the coal chemical industry in the coal industry, while the other six sectors should be limited.

Keywords: low carbon economy; industrial structure optimization; Grey Model $(1,1)$; grey dynamic linear programming model; mining economic region

\section{Introduction}

The global economy has developed rapidly since the industrialization period, which is closely linked to the abundant supply of resources. According to the theory of comparative advantage, abundant natural resources are the foundation of industrialization and economic development. Natural resources can provide the necessary material basis for economic growth and also improve national welfare.

Since the beginning of the 21 st century, issues regarding energy, particularly energy security, have received more attention. Energy is an important material basis for economic and social development, and a steady supply of energy is the premise of stable economic growth. Energy security is related to national security. For a long time, because of the endowment characteristics of the energy resources in China, coal has been the basic energy source and an important raw material in China, occupying an important strategic position in the national economy. In the coming few decades, coal resources will account for a decreasing ratio of the energy structure in China, while the status of coal as the main body of energy supply will remain unchanged. Shanxi province possesses rich coal resource and runs a typical resource-based economy in China. Coal resources occupy an important position in its industrial structure and economic development. The verified coal reserves in Shanxi province reach 2664 million tons - making it the second-largest reserve in China—and account for $22.6 \%$ of China's coal resources [1].

In the "11th Five-Year Plan" period, Shanxi province produced 3.22 billion tons of coal, which corresponds to an average annual increase of $6.32 \%$ and makes up approximately $23 \%$ of the total coal production in China over the same period. The amount of coal exported reached 2.49 billion tons, accounting for more than $70 \%$ of the inter-provincial coal transfer quantity.

Shanxi province has provided significant coal resources, making a great contribution to the national economic construction and reform. At the same time, coal mining has caused serious damage to the ecological environment, excessive use of resources, the deterioration of the ecological environment and a decline in the sustainable development capacity. This overreliance on a resource-based economy has led to problems such as an undeveloped economy and a single industrial structure. Therefore, the traditional model of economic development must be changed to improve the industrial structure.

A low carbon economy (LCE) is characterized by low consumption, low pollution and low emission. Adjusting the industrial structure will affect energy consumption and environmental pollution. Thus, adjusting the industrial structure to achieve LCE is a problem not only for Shanxi province but also for the sustainable development of the national economy. 


\section{Literature Review}

\subsection{Research on Grey System Model}

Grey system model has been widely used in agriculture, medicine, economy, ecology, culture, education, weather, traffic, transportation, management, industrial control and other fields by grey correlation analysis, gray prediction, grey clustering, gray decision, gray controlling, gray optimization and so on, to solve the practical problems in production, life and scientific research.

Mao, Duan, Li et al. [2] proposed and verified grey-correlation theory to analyze factors that may affect the selection of deep water platform, by choosing 13 main factors. The results showed that the optimal platform was identified as the one that had the highest relevance. Based on the grey prediction, Xiang, Xu, Li et al. [3] proposed a co-operative control mechanism to control the air supply flow of the air compressor. The statistical results demonstrated that the presented control mechanism could effectively reduce about $22 \%$ energy consumption of the air compressor. Wang, Cai, Xu et al. [4] developed a hybrid nonlinear grey-prediction and quota allocation model (HNGP-QAM) for China's carbon intensity reduction in 2020. The results showed that the total abatement cost would be $92.07 \times 10^{9}$ and $98.93 \times 10^{9}$, as well as $180.57 \times 10^{9}$ and $194.19 \times 10^{9} \mathrm{RMB}$ for provincial and departmental allocation schemes under the reduction ratios of $40 \%$ and $45 \%$, respectively. Liu, Shen, Tan et al. [5] recognized an effective grey clustering analysis method that has been put forward to deal with overseas project loans decision-making. Tai, Lin, Chen et al. [6] used a grey relation analysis and analytic hierarchy process to study the product development and competitiveness of an enterprise from limited data, taking a precision mechanical manufacturer as an example and proved this method feasible to make investment decisions.

Liu, Zhi, Wang et al. [7] designed a grey forecasting-optimal control scheme for a symmetric rotor bearing system based on the grey forecasting model Grey Model (GM) $(1,1)$ and the result shows that this theory and method of grey forecasting-optimal control was efficient and feasible for the vibration control of the rotor system. Wang and Tang [8] analyzed the agriculture and forestry herding fishery total production value structure, grain output structure, the meat output structure of Liaoning province using the grey incidence analysis of grey system theory, and this paper also used the GM $(1,1)$ model to predict the research series. Zhu and Gao [9] used grey correlation analysis and grey system prediction to analyze the forestry industrial structure of Heilongjiang Province and provided suggestions for optimizing and adjusting the forestry industrial structure of Heilongjiang Province.

\subsection{Research on LCE and Industrial Structure Adjustment}

Research on LCE had started based on the consideration of global climate change. There was strong scientific evidence that climate change has occurred and has been accelerated by human activities. In this situation, the UK government first proposed LCE in 2003 [10]. Since then, LCE has become a symbol of economic development. LCE is characterized by low energy consumption, low pollution and low emissions. LCE is the best pattern of economic development in the world to reduce the emission of greenhouse gas and mitigate climate change. LCE is more about the transform mode of economic development rather than a simple technical or mechanism issue. The core of the transformation of economic growth pattern is the industrial structure optimization. 
Most studies mainly focused on the relationship between LCE, economic growth and industrial structure adjustment. Soytas et al. [11] studied the relationship between energy consumption, economic growth and carbon emissions in the United States. The results revealed that a causal relationship existed between energy consumption and carbon emissions. Zhang and Xue [12] established a linear regression model on how the adjustment of the industrial structure impacts the carbon dioxide emissions based on the relevant time-series data of 1996-2009. The empirical results showed that (1) the type of industrial structure directly determined carbon emissions; (2) the secondary industry was positively related to carbon emissions; (3) and the development of a tertiary industry reduced carbon emissions. Liu, Duan, Zhang et al. [13] analyzed the process of low carbon development (LCD) and the industrial structure in the typical countries to reveal the causality relationship between LCD and industrial structure. The results revealed that the tertiary industry of China was the Granger cause of LCD with a $98 \%$ confidence interval, which suggested that the industrial structure should be adjusted before LCD, particularly the development of a tertiary industry. Zhang and Huang [14] analyzed the effects of industrial restructuring on carbon reduction and calculated both direct and indirect carbon emissions in 1997, 2000, 2002, 2005 and 2007 in Jiangsu province using an input-output analysis. The results indicated that the high carbon-reducing efficiency of a certain sector might be caused by its high direct carbon intensity, indirect carbon intensity or high economic status. Dong, Fujita, Zhang et al. [15] recognized that industrial symbiosis could contribute to a low-carbon city in terms of co-benefits.

The main concern regarding the optimization of the industrial structure is industry structure rationalization and gentrification. The rationalization of an industrial structure is a dynamic process of inter-industry coordination and mutual association. Regarding industry structure rationalization, much attention has been paid to judgment standards in foreign research. Industry structure gentrification is a dynamic process of an industry developing from a lower to a higher structure. The judgment standard is the standard structure of the value structure index or the labor structure index. Experts and scholars on industrial economics have conducted research on industrial structure and industrial structure gentrification since Kuznets' relevant research. Heston and Rouwenhorst [16] examined the influence of the industrial structure on the cross-sectional volatility and correlation structure of the country index returns for 12 European countries between 1978 and 1992. The results showed that the industrial structure explained very little of the cross-sectional differences in the country return volatilities. Peneder [17] applied dynamic panel estimations based on data of 28 Organization for Economic Co-operation and Development (OECD) countries, and the results confirmed that the industrial structure had been a significant determinant of macroeconomic development and growth in the 1990s. Zhang, Deng [18] made use of environmental influence modulus of industrial departments (EIMID) and quantitatively evaluated the entire eco-environmental impact of the industrial structure change in Chongqing from 1997 to 2008 by integrated eco-environmental influence modulus of industrial structure (IEIMIS). The results showed that the industrial structure had experienced two significant transformations since the establishment of the municipality in 1997 and that IEIMIS presented an approximate U-shaped curve with an ascent trend after an initial decline and fluctuated in a certain range. Chivu and Ciutacu [19] approached the restructuring of the Romanian industry. The paper addressed the decomposition and recomposition of Romania's industrial structure from a national perspective, without ignoring the trends in the European industrial strategies and policies. 
The study on the optimization of the industrial structure in China stemmed from the readjustment of the industrial structure to achieve steady economic growth. Zhou [20] recognized that China's industrial structure had been improved and that the ratio of agriculture, light industry, heavy industry in the national economy was becoming more balanced. Wang and Liu [21] calculated the total benefits in all sectors and quantified the sectors of the national economy to optimize the industrial structure using the input-output method. According to the scientific development concept, Ning and $\mathrm{Xu}$ [22] analyzed the development of the coal industry in Shanxi province.

Qiao [23] analyzed the structure of the Shanxi coal industry in regards to industrial quality and found that the structure was insufficient, the primary processing and deep processing was inharmonious, and the development of related industries was relatively lagging behind. Man, Zhu [24] studied the industrial structure of Yunnan province using the grey relational model. Li [25] optimized the industrial structure of Henan province using the gray dynamic linear programming. Based on rough set theory, Li, Li and Wang [26] evaluated the rationalization of the industrial structure in Xinjiang Production and Construction Corps during the period from 2001 to 2010. The results showed that the rationalization of the industrial structure in Xinjiang Production and Construction Corps was gradually rising; however, overall, the rationalization level of the industrial structure was still not high.

Reviewing literature on LCE and industrial structure adjustment, the paper found the following deficiencies:

(1) Previous research rarely discusses LCE together with industrial structure optimization, where either the optimization of the industrial structure or LCE is focused.

(2) The way to achieve LCE with the optimization of the industrial structure is seldom discussed in previous literature. LCE will be the main pattern of future economic development. Different development patterns will fit to different regions. So it is important to discuss the different ways for different regions to achieve LCE.

Coal-dominated industrial structure is the current development situation of the energy industry in Shanxi province. There are certain limitations regarding the coordinated development of the economy and environment in Shanxi province. The optimization of the three industrial structures and the energy industrial structure is currently of upmost importance in the transformation of Shanxi province. Therefore, this paper mainly studies the optimization of the industrial structure in Shanxi province under the background of an LCE development pattern.

\section{Model and Data}

At first, this paper predicts the coefficients of the capital investments, power and $\mathrm{CO}_{2}$ emissions using the Grey Model $(1,1)(\operatorname{GM}(1,1))$. Secondly, according to the objective function, constraints and the coefficients of the capital investments, power and the $\mathrm{CO}_{2}$ emissions predicted by the $\mathrm{GM}(1,1)$ model, the paper establishes the dynamic grey linear programming model of the optimization of industrial structure for Shanxi province during the period from 2015 to 2020. 


\subsection{GM $(1,1)$ Model}

Grey system theory, fuzzy mathematics and probability statistics are the three research methods used most commonly of uncertainty system. The grey system model is suitable for incomplete information, which is able to reduce the uncertainty of the model that fuzzy mathematics, probability statistics cannot (Table 1) [27]. In 1980s, Professor Julong Deng proposed the theory of grey system. By establishing the differential equation model, the grey system model utilizes and processes the dynamic information. In the process of building the model, the grey system theory makes full use of the information displayed by the limited data and the underlying information.

Table 1. Comparison of the three kinds of uncertainty research methods.

\begin{tabular}{cccc}
\hline Subject & Grey System & Probability Statistics & Fuzzy Mathematics \\
\hline subject investigated & uncertaint poor information & uncertaint random & uncertaint cognition \\
elementary set & Grey hazy set & Cantor set & fuzzy sets \\
method & overlaying information & mapping & mapping \\
ways and measure & grey sequence operator & frequency statistics & cut set \\
data requirement & random distribution & canonical distribution & knowing membership grade \\
focus & connotation & connotation & extension \\
objective & realistic law & historical statistical law & cognitive expression \\
feature & small sample & big sample & by experience \\
\hline
\end{tabular}

GM $(1,1)$ model is a grey system model. At present, to reveal the change law of the main factors and the future trend, the GM $(1,1)$ model is a dynamic grey prediction model that is mainly used for value fitting and forecasting of a major factor in a complex system [28]. GM $(1,1)$ model is a differential equation model with first-order and a variable [27].

Assuming that there are $N$ observations in the time series,

$$
x^{(0)}=\left[x^{(0)}(1), x^{(0)}(2), \ldots, x^{(0)}(n)\right]
$$

The new sequence additionally generated is:

$$
x^{(1)}=\left[x^{(1)}(1), x^{(1)}(2), \ldots, x^{(1)}(n)\right]
$$

Assuming $Z^{(1)}$ is close to the mean generation sequence of $x^{(1)}$ :

$$
\begin{gathered}
z^{(1)}=\left[z^{(1)}(2), z^{(1)}(3) \ldots, z^{(1)}(n)\right] \\
z^{(1)}(k)=1 / 2\left[x^{(1)}(k-1)+x^{(1)}(k)\right]
\end{gathered}
$$

Making:

$$
x^{(0)}(k)+a z^{(1)}(k)=b
$$

the grey differential equation model of $\operatorname{GM}(1,1)$.

Where:

$a$ is the developmental quotient, showing the development trends of $x^{(0)}$ and $x^{(1)}$;

$b$ is the endogenous control grey number; and

$Z^{(1)}(k)$ is the sequence value of the white background. 
The paper chooses and establishes the GM $(1,1)$ model using the existing data to forecast the investment, power input, and carbon emissions in future periods. Then, the GM $(1,1)$ model is established again to predict the coefficients of the resources and environment consumption.

\subsection{Dynamic Grey Linear Programming Model}

The optimization of the industrial structure mainly refers to the process of coordinated development, which can continuously improve the overall level of the industry. Its essence is the optimization of resource allocation and efficient utilization to realize a stable and coordinated development in the industrial economy.

Against the background of LCE, to achieve stable and rapid economic growth in Shanxi province, the paper takes economic growth as the objective function, and the resources, environment, investment and output value of the three industries as the constraint conditions to build the optimization model. In the short term, the industrial development scale of the three industries changes only slightly; therefore, this paper constrains the output value scale of industry $i$ to be between GDP minus $2 \%$ and GDP plus $2 \%$.

Based on the objective and the constraints of the industrial structure optimization in Shanxi province, the paper designs the model of the optimization of industrial structure [29]. The output value of the primary industry, the secondary industry and the tertiary industry is expressed by $x_{1}, x_{2}$ and $x_{3}$, respectively, $a_{1}$ and $b_{2}$ represent the capital investments (100 million yuan) and power inputs (100 million kilowatt-hours), respectively, and $\mathrm{c}_{3}$ represents the total $\mathrm{CO}_{2}$ emissions.

At the same time, the paper defines that:

$a_{1 i}$ is the capital investment needed in 100 million yuan in the three industries in Shanxi province (100 million yuan/100 million yuan);

$b_{2 i}$ is the power needed in 100 million yuan in the three industries in Shanxi province (100 million kilowatt-hours/100 million yuan);

$c_{3 i}$ is the direct emission coefficient of $\mathrm{CO}_{2}$ in 100 million yuan in the three industries in Shanxi province.

The grey dynamic linear programming model established is as follows:

$$
\max Z(x)=x_{1}+x_{2}+x_{3}
$$

Constraint conditions:

$$
\left\{\begin{array}{c}
a_{11} x_{1}+a_{12} x_{2}+a_{13} x_{3} \leq a_{1} \\
b_{21} x_{1}+b_{22} x_{2}+a_{23} x_{3} \leq b_{2} \\
c_{31} x_{1}+c_{32} x_{2}+a_{33} x_{3} \leq c_{3} \\
x_{1}, x_{2}, x_{3} \geq 0
\end{array}\right.
$$

First, the paper establishes the GM $(1,1)$ model using the relevant data from 2007 to 2011; then, $a_{1}$, $b_{2}, c_{3}$ and $a_{1 i}, b_{2 i}, c_{3 i}$ are predicted. Based on the prediction results, the paper calculates the consumption coefficients of the resources and the environment from 2015 to 2020.

According to the objective function and the constraints established, the paper builds the grey dynamic linear programming model from year $n$ to year $n+m$ in the future. Thus, the optimal industrial structure during the period from 2015 to 2020 can be calculated. 


$$
\begin{gathered}
\max Z_{n}=x_{1}^{n}+x_{2}^{n}+x_{3}^{n} \\
\left\{\begin{array}{c}
a_{11}^{n} x_{1}^{n}+a_{12}^{n} x_{2}^{n}+a_{13}^{n} x_{3}^{n} \leq a_{1}^{n} \\
b_{21}^{n} x_{1}^{n}+b_{22}^{n} x_{2}^{n}+b_{23}^{n} x_{3}^{n} \leq b_{2}^{n} \\
c_{31}^{n} x_{1}^{n}+c_{32}^{n} x_{2}^{n}+c_{33}^{n} x_{3}^{n} \leq c_{3}^{n} \\
x_{1}^{n} \geq 0, x_{2}^{n} \geq 0, x_{3}^{n} \geq 0 \\
\cdots \cdots
\end{array}\right. \\
\max Z_{n+m}=x_{1}^{n+m}+x_{2}^{n+m}+x_{3}^{n+m} \\
\left\{\begin{array}{c}
a_{11}^{n+m} x_{1}^{n+m}+a_{12}^{n+m} x_{2}^{n+m}+a_{13}^{n+m} x_{3}^{n+m} \leq a_{1}^{n+m} \\
b_{21}^{n+m} x_{1}^{n+m}+b_{22}^{n+m} x_{2}^{n+m}+b_{23}^{n+m} x_{3}^{n+m} \leq b_{2}^{n+m} \\
c_{31}^{n+m} x_{1}^{n+m}+c_{32}^{n+m} x_{2}^{n+m}+c_{33}^{n+m} x_{3}^{n+m} \leq c_{3}^{n+m} \\
x_{1}^{n+m} \geq 0, x_{2}^{n+m} \geq 0, x_{3}^{n+m} \geq 0
\end{array}\right.
\end{gathered}
$$

\subsection{Data}

The data of the three industries and the seven largest carbon-emitting industries in the secondary industry from 2007 to 2011 in Shanxi province are all from the Shanxi statistical yearbooks from 2008 to 2012 and the calculated results.

\section{Results and Discussion}

\subsection{Structure Optimization in the Three Industries}

The data of GDP, the total capital investments and the capital investments needed per 100 million yuan, the total power used and the power needed per 100 million yuan, the total carbon emissions and carbon emissions per 100 million yuan in Shanxi Province from 2007 to 2011 are shown in Tables 2-5.

The paper establishes the GM $(1,1)$ model using the grey system theory and predicts the capital investment, power input and $\mathrm{CO}_{2}$ emissions of Shanxi province from 2015 to 2020. The prediction results are shown in Tables 6-9 in the following.

According to the objective function and the constraints established, the paper establishes the grey dynamic linear programming model to design the structure optimization of the three industries from 2015 to 2020 using Lingo 9.0 (Lindo Systems Inc., Chicago, IL, USA). The optimization design of the three industrial structures is shown in Table 10.

Table 2. GDP in Shanxi Province from 2007 to 2011 (100 million yuan) [30-34].

\begin{tabular}{cccc}
\hline Year & The Primary Industry & The Secondary Industry & The Tertiary Industry \\
\hline 2007 & 311.97 & 3438.6 & 2257.99 \\
2008 & 313.58 & 4179.7 & 2759.46 \\
2009 & 477.59 & 1800.1 & 2886.92 \\
2010 & 554.48 & 5234 & 3412.38 \\
2011 & 641.42 & 6635.3 & 3960.87 \\
\hline
\end{tabular}


Table 3. The total capital investments and the capital investments needed per 100 million yuan in Shanxi Province from 2007 to 2011 (100 million yuan) [30-34].

\begin{tabular}{ccccccc}
\hline \multirow{2}{*}{ Year } & \multicolumn{3}{c}{ The Total Capital Investments } & \multicolumn{2}{c}{ The Capital Investments Needed per 100 Million Yuan } \\
\cline { 2 - 6 } & $\begin{array}{c}\text { The Primary } \\
\text { Industry }\end{array}$ & $\begin{array}{c}\text { The Secondary } \\
\text { Industry }\end{array}$ & $\begin{array}{c}\text { The Tertiary } \\
\text { Industry }\end{array}$ & $\begin{array}{c}\text { The Primary } \\
\text { Industry }\end{array}$ & $\begin{array}{c}\text { The Secondary } \\
\text { Industry }\end{array}$ & $\begin{array}{c}\text { The Tertiary } \\
\text { Industry }\end{array}$ \\
\hline 2007 & 83.8947 & 1617.15 & 1226.12 & 0.2689191 & 0.4702936 & 0.5430134 \\
2008 & 111.9701 & 1868.89 & 1654.28 & 0.3570703 & 0.4471351 & 0.5994937 \\
2009 & 220.3844 & 2163.60 & 2649.55 & 0.461451 & 1.2019343 & 0.9177764 \\
2010 & 281.2813 & 2628.13 & 3443.19 & 0.5072885 & 0.5021261 & 1.0090294 \\
2011 & 271.2048 & 3348.58 & 3753.27 & 0.4228194 & 0.5046616 & 0.9475878 \\
\hline
\end{tabular}

Table 4. The total power used and the power needed per 100 million yuan in Shanxi Province from 2007 to 2011 (100 million Kwh) [30-34].

\begin{tabular}{ccccccc}
\hline \multirow{3}{*}{ Year } & \multicolumn{3}{c}{ The Total Power Used } & \multicolumn{2}{c}{ The Power Needed per 100 Million Yuan } \\
\cline { 2 - 6 } & $\begin{array}{c}\text { The Primary } \\
\text { Industry }\end{array}$ & $\begin{array}{c}\text { The Secondary } \\
\text { Industry }\end{array}$ & $\begin{array}{c}\text { The Tertiary } \\
\text { Industry }\end{array}$ & $\begin{array}{c}\text { The Primary } \\
\text { Industry }\end{array}$ & $\begin{array}{c}\text { The Secondary } \\
\text { Industry }\end{array}$ & $\begin{array}{c}\text { The Tertiary } \\
\text { Industry }\end{array}$ \\
\hline 2007 & 28.38 & 1086.48 & 91.05 & 0.090970 & 0.315967 & 0.040323 \\
2008 & 27.32 & 1036.13 & 95.07 & 0.087123 & 0.247896 & 0.034452 \\
2009 & 32.04 & 967.64 & 102.36 & 0.067087 & 0.537548 & 0.035456 \\
2010 & 35.14 & 1127.39 & 113.24 & 0.063375 & 0.215397 & 0.033185 \\
2011 & 38.74 & 1291.57 & 126.02 & 0.060397 & 0.194651 & 0.031816 \\
\hline
\end{tabular}

Table 5. The total carbon emissions and carbon emissions per 100 million yuan in Shanxi Province from 2007 to 2011 (100 million tons). Sources: Calculating according to the data from [30-34].

\begin{tabular}{ccccccc}
\hline \multirow{2}{*}{ Year } & \multicolumn{3}{c}{ The Total Carbon Emissions } & \multicolumn{2}{c}{ Carbon Emissions per 100 Million Yuan } \\
\cline { 2 - 7 } & $\begin{array}{c}\text { The Primary } \\
\text { Industry }\end{array}$ & $\begin{array}{c}\text { The Secondary } \\
\text { Industry }\end{array}$ & $\begin{array}{c}\text { The Tertiary } \\
\text { Industry }\end{array}$ & $\begin{array}{c}\text { The Primary } \\
\text { Industry }\end{array}$ & $\begin{array}{c}\text { The Secondary } \\
\text { Industry }\end{array}$ & $\begin{array}{c}\text { The Tertiary } \\
\text { Industry }\end{array}$ \\
\hline 2007 & 0.03871974 & 5.900752 & 0.2996645 & 0.00012411 & 0.001716 & 0.000133 \\
2008 & 0.03662482 & 5.669543 & 0.4050779 & 0.00011680 & 0.001356 & 0.000147 \\
2009 & 0.05852801 & 5.465144 & 0.5245357 & 0.00012255 & 0.003036 & 0.000182 \\
2010 & 0.05843123 & 5.94221 & 0.4903828 & 0.00010538 & 0.001135 & 0.000144 \\
2011 & 0.059593 & 6.443358 & 0.520116 & 0.00009292 & 0.000971 & 0.000131 \\
\hline
\end{tabular}

Table 6. Predicted values of the capital investment, power input and $\mathrm{CO}_{2}$ emissions.

\begin{tabular}{cccc}
\hline Year & $\begin{array}{c}\text { Capital Investment/ } \\
\text { 100 Million Yuan }\end{array}$ & $\begin{array}{c}\text { Power Input/ } \\
\text { 100 Million Kilowatt-Hours }\end{array}$ & $\begin{array}{c}\text { CO}_{2} \text { Emissions/ } \\
\text { 100 Million Tons }\end{array}$ \\
\hline 2015 & 18970.63 & 2249.32 & 371.36 \\
2016 & 23876.37 & 2512.45 & 426.84 \\
2017 & 30051.06 & 2806.42 & 490.46 \\
2018 & 37823.01 & 3134.82 & 563.58 \\
2019 & 47605.49 & 3501.74 & 746.59 \\
2020 & 59918.75 & 3911.66 & 744.12 \\
\hline
\end{tabular}


Table 7. Predicted values of the capital investments needed per 100 million yuan (100 million yuan).

\begin{tabular}{cccc}
\hline Year & The Primary Industry & The Secondary Industry & The Tertiary Industry \\
\hline 2015 & 0.4765373 & 0.4985370 & 1.5235776 \\
2016 & 0.4820308 & 0.4971360 & 1.6883489 \\
2017 & 0.4875908 & 0.4957384 & 1.8709404 \\
2018 & 0.4932122 & 0.494345 & 2.0732773 \\
2019 & 0.4988983 & 0.4929555 & 2.2974992 \\
2020 & 0.5046527 & 0.4915698 & 2.545967 \\
\hline
\end{tabular}

Table 8. Predicted values of the power needed in 100 million yuan (100 million kilowatt-hours).

\begin{tabular}{cccc}
\hline Year & The Primary Industry & The Secondary Industry & The Tertiary Industry \\
\hline 2015 & 0.04069853 & 0.12094684 & 0.027997677 \\
2016 & 0.037038651 & 0.10737497 & 0.02706383 \\
2017 & 0.033712301 & 0.09532608 & 0.026160247 \\
2018 & 0.030680587 & 0.0846289 & 0.025286528 \\
2019 & 0.027921686 & 0.07513242 & 0.02444315 \\
2020 & 0.025412684 & 0.06670138 & 0.023626596 \\
\hline
\end{tabular}

Table 9. Predicted values of the total $\mathrm{CO}_{2}$ emissions in 100 million yuan (100 million tons).

\begin{tabular}{cccc}
\hline Year & The Primary Industry & The Secondary Industry & The Tertiary Industry \\
\hline 2015 & 0.00491449 & 0.01833998 & 0.00758821 \\
2016 & 0.00433323 & 0.01668411 & 0.00750765 \\
2017 & 0.00336881 & 0.01517773 & 0.00742795 \\
2018 & 0.00297036 & 0.01380737 & 0.00734910 \\
2019 & 0.00261904 & 0.01256073 & 0.00727108 \\
2020 & 0.00230927 & 0.01142665 & 0.00719389 \\
\hline
\end{tabular}

Table 10. Optimization design of the three industrial structures in Shanxi province (\%).

\begin{tabular}{cccc}
\hline \multirow{2}{*}{ Year } & The Primary Industry & The Secondary Industry & The Tertiary Industry \\
\cline { 2 - 4 } & $\begin{array}{c}\text { The GDP Proportion of the } \\
\text { Output Value }\end{array}$ & $\begin{array}{c}\text { The GDP Proportion of the } \\
\text { Output Value }\end{array}$ & $\begin{array}{c}\text { The GDP Proportion of the } \\
\text { Output Value }\end{array}$ \\
\hline 2015 & 5.62 & 46.16 & 48.22 \\
2016 & 5.65 & 44.83 & 49.53 \\
2017 & 5.69 & 43.62 & 50.69 \\
2018 & 5.75 & 42.52 & 51.73 \\
2019 & 5.81 & 41.51 & 52.68 \\
2020 & 5.88 & 40.58 & 53.54 \\
\hline
\end{tabular}

From Table 10, it can be seen that the three industrial structures are 5.62:46.16:48.22 in 2015, which can be changed to 5.88:40.58:53.54 in 2020. The GDP proportion of the output value of the primary industry remains basically unchanged. Because of resource depletion, environmental pollution and some other reasons, Shanxi province should vigorously promote the economy's move toward a low carbon development pattern. Thus, the GDP proportion of the output value of the secondary 
industry continues to decline. The GDP proportion of the output value of the tertiary industry increases steadily, which is consistent with the sharp rise in investment of the tertiary industry in Shanxi province.

\subsection{Structure Optimization of the Seven Largest Sectors in Terms of Carbon Emissions in the Secondary Industry}

Taking carbon emissions as the indicator, the paper chooses the seven largest industries in terms of carbon emissions in the secondary industry for optimization, which are the coal-mining and washing industry, the oil-processing and coking industry, the chemical raw materials manufacturing industry, the ferrous metal smelting industry, the non-ferrous metal smelting and processing industry, the electric power production and supply industry and the construction industry using the data of Tables 11-17. The predicted results are shown in Tables 18-22.

According to the objective function and the constraints established, the paper establishes the grey dynamic linear programming model to design the structure optimization of the seven largest industries in terms of carbon emissions in the secondary industry from 2015 to 2020 in Table 22 using lingo 9.0.

From Table 22, it can be seen that in the optimization design of the seven largest industries in terms of carbon emissions in the secondary industry, the GDP proportion of the output value of the coal-mining and washing industry increases steadily, while the proportions of the output value in the other six industries continue to decline.

\subsection{Discussion}

In contrast to the previous research that mainly focused on the relationship between LCE, economic growth and industrial structure, this paper analyzes the optimization of the industrial structure in Shanxi province against the background of LCE development. The reliance of the methods and results depends on the following explanation.

(1) On the model

This paper utilizes the GM $(1,1)$ model and the dynamic grey linear programming model to optimize the industrial structure in Shanxi province from 2015 to 2020. This method is appropriate because the grey system models are suitable for incomplete information and increase the certainty. Li [17] and Dang et al. [20] also used the same models, and their results showed that the models are suitable to optimize industrial structure.

(2) On the optimization results

In the structure optimization of the three industries in Shanxi province from 2015 to 2020, the GDP proportion of the output value in the primary industry remained basically unchanged, which will maintain the fundamental position of agriculture. The GDP proportion of the output value in the secondary industry continues to decline. Due to the development of the secondary industry, resource exhaustion and environmental pollution in Shanxi province is increasing, which should promote the economy move towards a low carbon development pattern. The GDP proportion of the output value in the tertiary industry increases steadily, which is consistent with a transformation of the resource-based economy in Shanxi province. 
Table 11. Gross output value of industries in Shanxi Province from 2007 to 2011 (10 thousand yuan) [30-34].

\begin{tabular}{|c|c|c|c|c|c|c|c|}
\hline Year & $\begin{array}{l}\text { Coal-Mining and } \\
\text { Washing Industry }\end{array}$ & $\begin{array}{c}\text { Oil-Processing and } \\
\text { Coking Industry } \\
\end{array}$ & $\begin{array}{l}\text { Chemical-Raw-Materials } \\
\text { Manufacturing Industry }\end{array}$ & $\begin{array}{c}\text { Ferrous Metal } \\
\text { Smelting Industry }\end{array}$ & $\begin{array}{c}\text { Non-Ferrous Metal Smelting } \\
\text { and Processing Industry }\end{array}$ & $\begin{array}{c}\text { Electric Power Production } \\
\text { and Supply Industry }\end{array}$ & $\begin{array}{c}\text { Construction } \\
\text { Industry } \\
\end{array}$ \\
\hline 2007 & $21,703,894$ & $9,932,739$ & $4,266,570$ & $17,365,064$ & $4,265,023$ & $7,499,370$ & $10,607,041$ \\
\hline 2008 & $33,561,157$ & $15,609,468$ & $4,684,572$ & $18,999,334$ & $4,221,897$ & $8,254,442$ & $13,554,415$ \\
\hline 2009 & $34,215,763$ & $11,554,569$ & $4,166,784$ & $15,325,316$ & $2,743,905$ & $9,261,297$ & $18,261,040$ \\
\hline 2010 & $47,412,112$ & $14,620,883$ & $5,094,686$ & $19,975,177$ & $4,041,938$ & $11,094,353$ & $21,434,591$ \\
\hline 2011 & $64,505,823$ & $17,017,687$ & $6,245,288$ & $26,714,122$ & $5,163,591$ & $12,737,036$ & $23,249,108$ \\
\hline
\end{tabular}

Table 12. The total capital investments of industries in Shanxi Province from 2007 to 2011 (10 thousand yuan) [30-34].

\begin{tabular}{|c|c|c|c|c|c|c|c|}
\hline Year & $\begin{array}{l}\text { Coal-Mining and } \\
\text { Washing Industry }\end{array}$ & $\begin{array}{c}\text { Oil-Processing and } \\
\text { Coking Industry } \\
\end{array}$ & $\begin{array}{l}\text { Chemical-Raw-Materials } \\
\text { Manufacturing Industry }\end{array}$ & $\begin{array}{c}\text { Ferrous Metal } \\
\text { Smelting Industry }\end{array}$ & $\begin{array}{c}\text { Non-Ferrous Metal Smelting } \\
\text { and Processing Industry }\end{array}$ & $\begin{array}{c}\text { Electric Power Production } \\
\text { and Supply Industry }\end{array}$ & $\begin{array}{c}\text { Construction } \\
\text { Industry } \\
\end{array}$ \\
\hline 2007 & $3,639,235$ & 923,172 & $1,058,665$ & $1,876,299$ & 392,544 & $4,188,752$ & 95,085 \\
\hline 2008 & $4,640,781$ & $1,014,761$ & $1,539,122$ & $1,475,297$ & 847,459 & $4,757,173$ & 168,864 \\
\hline 2009 & $5,986,723$ & $1,025,476$ & $1,028,347$ & $1,193,801$ & 726,107 & $5,360,840$ & 216,531 \\
\hline 2010 & $9,295,058$ & 964,168 & $1,111,495$ & $1,147,203$ & 721,708 & $5,196,638$ & 166,365 \\
\hline 2011 & $12,402,352$ & 984,261 & $1,666,503$ & $1,345,978$ & $1,145,792$ & $5,476,398$ & 89,150 \\
\hline
\end{tabular}

Table 13. The capital investments needed per 10 thousand yuan of industries in Shanxi Province from 2007 to 2011 (10 thousand yuan).

\begin{tabular}{|c|c|c|c|c|c|c|c|}
\hline Year & $\begin{array}{l}\text { Coal-Mining and } \\
\text { Washing Industry }\end{array}$ & $\begin{array}{c}\text { Oil-Processing and } \\
\text { Coking Industry }\end{array}$ & $\begin{array}{l}\text { Chemical-Raw-Materials } \\
\text { Manufacturing Industry }\end{array}$ & $\begin{array}{c}\text { Ferrous Metal } \\
\text { Smelting Industry }\end{array}$ & $\begin{array}{c}\text { Non-Ferrous Metal Smelting } \\
\text { and Processing Industry }\end{array}$ & $\begin{array}{c}\text { Electric Power Production } \\
\text { and Supply Industry }\end{array}$ & $\begin{array}{c}\text { Construction } \\
\text { Industry }\end{array}$ \\
\hline 2007 & 0.167676 & 0.092942 & 0.24813 & 0.10805 & 0.092038 & 0.558547 & 0.008964 \\
\hline 2008 & 0.138278 & 0.065009 & 0.328551 & 0.07765 & 0.200729 & 0.576317 & 0.012458 \\
\hline 2009 & 0.174969 & 0.088751 & 0.246796 & 0.077897 & 0.264625 & 0.578843 & 0.011858 \\
\hline 2010 & 0.196048 & 0.065945 & 0.218168 & 0.057431 & 0.178555 & 0.468404 & 0.007762 \\
\hline 2011 & 0.192267 & 0.057837 & 0.266842 & 0.050385 & 0.221898 & 0.429959 & 0.003835 \\
\hline
\end{tabular}


Table 14. The total power used of industries in Shanxi Province from 2007 to 2011 (10 thousand Kwh) [30-34].

\begin{tabular}{|c|c|c|c|c|c|c|c|}
\hline Year & $\begin{array}{l}\text { Coal-Mining and } \\
\text { Washing Industry }\end{array}$ & $\begin{array}{c}\text { Oil-Processing and } \\
\text { Coking Industry }\end{array}$ & $\begin{array}{l}\text { Chemical-Raw-Materials } \\
\text { Manufacturing Industry }\end{array}$ & $\begin{array}{c}\text { Ferrous Metal } \\
\text { Smelting Industry }\end{array}$ & $\begin{array}{c}\text { Non-Ferrous Metal Smelting } \\
\text { and Processing Industry }\end{array}$ & $\begin{array}{c}\text { Electric Power Production } \\
\text { and Supply Industry }\end{array}$ & $\begin{array}{c}\text { Construction } \\
\text { Industry }\end{array}$ \\
\hline 2007 & $1,425,100$ & 679,600 & $1,436,100$ & $2,009,100$ & $1,735,300$ & $1,627,800$ & 81,400 \\
\hline 2008 & $1,783,300$ & 505,500 & $1,522,300$ & $1,701,800$ & $1,707,300$ & $1,670,600$ & 94,500 \\
\hline 2009 & $1,508,300$ & 252,001 & $1,257,700$ & $1,799,600$ & $1,380,200$ & $1,680,900$ & 112,000 \\
\hline 2010 & $1,718,500$ & 303,000 & $1,323,400$ & $2,096,400$ & $1,639,100$ & $2,725,600$ & 161,800 \\
\hline 2011 & $1,943,100$ & 405,300 & $1,500,005$ & $2,223,300$ & $1,822,400$ & $2,934,000$ & 206,100 \\
\hline
\end{tabular}

Table 15. The power needed per 10 thousand yuan of industries in Shanxi Province from 2007 to 2011 (10 thousand Kwh).

\begin{tabular}{|c|c|c|c|c|c|c|c|}
\hline Year & $\begin{array}{l}\text { Coal-Mining and } \\
\text { Washing Industry }\end{array}$ & $\begin{array}{l}\text { Oil-Processing and } \\
\text { Coking Industry }\end{array}$ & $\begin{array}{l}\text { Chemical-Raw-Materials } \\
\text { Manufacturing Industry }\end{array}$ & $\begin{array}{c}\text { Ferrous Metal } \\
\text { Smelting Industry }\end{array}$ & $\begin{array}{c}\text { Non-Ferrous Metal Smelting } \\
\text { and Processing Industry }\end{array}$ & $\begin{array}{c}\text { Electric Power Production } \\
\text { and Supply Industry }\end{array}$ & $\begin{array}{c}\text { Construction } \\
\text { Industry }\end{array}$ \\
\hline 2007 & 0.06566 & 0.068420 & 0.336594 & 0.115698 & 0.406868 & 0.217058 & 0.007674 \\
\hline 2008 & 0.053135 & 0.032384 & 0.32496 & 0.089572 & 0.404392 & 0.202388 & 0.006972 \\
\hline 2009 & 0.044082 & 0.021809 & 0.30184 & 0.117427 & 0.503006 & 0.181497 & 0.006133 \\
\hline 2010 & 0.036246 & 0.020723 & 0.259761 & 0.10495 & 0.405523 & 0.245675 & 0.007549 \\
\hline 2011 & 0.030122 & 0.023816 & 0.240182 & 0.083226 & 0.352933 & 0.230352 & 0.008865 \\
\hline
\end{tabular}

Table 16. The total carbon emissions of industries in Shanxi Province from 2007 to 2011 (10 thousand tons). Sources: Calculating according to the data from [30-34].

\begin{tabular}{|c|c|c|c|c|c|c|c|}
\hline Year & $\begin{array}{l}\text { Coal-Mining and } \\
\text { Washing Industry }\end{array}$ & $\begin{array}{c}\text { Oil-Processing and } \\
\text { Coking Industry }\end{array}$ & $\begin{array}{l}\text { Chemical-Raw-Materials } \\
\text { Manufacturing Industry }\end{array}$ & $\begin{array}{c}\text { Ferrous Metal } \\
\text { Smelting Industry }\end{array}$ & $\begin{array}{c}\text { Non-Ferrous Metal Smelting } \\
\text { and Processing Industry }\end{array}$ & $\begin{array}{c}\text { Electric Power Production } \\
\text { and Supply Industry }\end{array}$ & $\begin{array}{c}\text { Construction } \\
\text { Industry }\end{array}$ \\
\hline 2007 & $1,778,868$ & 870,800 & $1,792,292$ & $2,512,179$ & $2,164,377$ & $2,042,162$ & 101,590 \\
\hline 2008 & $2,226,749$ & 650,491 & $1,899,871$ & $2,128,707$ & $2,129,233$ & $2,095,886$ & 117,956 \\
\hline 2009 & $1,884,004$ & 333,158 & $1,569,999$ & $2,250,237$ & $1,721,167$ & $2,108,982$ & 139,775 \\
\hline 2010 & $2,146,578$ & 397,604 & $1,651,545$ & $2,621,066$ & $2,043,790$ & $3,413,503$ & 201,825 \\
\hline 2011 & $2,426,590$ & 527,210 & $1,872,339$ & $2,780,140$ & $2,272,340$ & $3,673,778$ & 257,018 \\
\hline
\end{tabular}


Table 17. The carbon emissions per 10 thousand yuan of industries in Shanxi Province from 2007 to 2011 (10 thousand tons).

\begin{tabular}{|c|c|c|c|c|c|c|c|}
\hline Year & $\begin{array}{l}\text { Coal-Mining and } \\
\text { Washing Industry }\end{array}$ & $\begin{array}{c}\text { Oil-Processing and } \\
\text { Coking Industry }\end{array}$ & $\begin{array}{l}\text { Chemical-Raw-Materials } \\
\text { Manufacturing Industry }\end{array}$ & $\begin{array}{c}\text { Ferrous Metal } \\
\text { Smelting Industry }\end{array}$ & $\begin{array}{c}\text { Non-Ferrous Metal Smelting } \\
\text { and Processing Industry }\end{array}$ & $\begin{array}{c}\text { Electric Power Production } \\
\text { and Supply Industry }\end{array}$ & $\begin{array}{c}\text { Construction } \\
\text { Industry } \\
\end{array}$ \\
\hline 2007 & 0.081961 & 0.08767 & 0.420078 & 0.144669 & 0.507471 & 0.272311 & 0.009578 \\
\hline 2008 & 0.066349 & 0.041673 & 0.405559 & 0.112041 & 0.504331 & 0.25391 & 0.008702 \\
\hline 2009 & 0.055062 & 0.028833 & 0.376789 & 0.146831 & 0.627269 & 0.22772 & 0.007654 \\
\hline 2010 & 0.045275 & 0.027194 & 0.32417 & 0.131216 & 0.505646 & 0.307679 & 0.009416 \\
\hline 2011 & 0.037618 & 0.03098 & 0.2998 & 0.10407 & 0.44007 & 0.288433 & 0.011055 \\
\hline
\end{tabular}

Table 18. Predicted values of the capital investment, power input and $\mathrm{CO}_{2}$ emissions.

\begin{tabular}{cccc}
\hline Year & Capital Investment /100 Million Yuan & Power Input/100 Million Kilowatt-Hours & $\mathbf{C O}_{\mathbf{2}}$ Emissions /100 Million Tons \\
\hline 2015 & $59,539,891$ & $16,518,971$ & $19,206,750$ \\
2016 & $78,991,852$ & $18,898,763$ & $20,793,691$ \\
2017 & $106,227,835$ & $23,884,807$ & $22,562,780$ \\
2018 & $143,730,132$ & $27,844,252$ & $24,546,656$ \\
2019 & $195,919,754$ & $32,649,139$ & $26,786,167$ \\
2020 & $268,633,928$ & $38,496,441$ & $29,332,778$ \\
\hline
\end{tabular}

Table19. Predicted values of the capital investments needed per 10 thousand yuan (10 thousand yuan).

\begin{tabular}{|c|c|c|c|c|c|c|c|}
\hline Year & $\begin{array}{l}\text { Coal-Mining and } \\
\text { Washing Industry }\end{array}$ & $\begin{array}{l}\text { Oil-Processing and } \\
\text { Coking Industry }\end{array}$ & $\begin{array}{l}\text { Chemical-Raw-Materials } \\
\text { Manufacturing Industry }\end{array}$ & $\begin{array}{c}\text { Ferrous Metal } \\
\text { Smelting Industry }\end{array}$ & $\begin{array}{c}\text { Non-Ferrous Metal Smelting } \\
\text { and Processing Industry }\end{array}$ & $\begin{array}{c}\text { Electric Power Production } \\
\text { and Supply Industry }\end{array}$ & $\begin{array}{c}\text { Construction } \\
\text { Industry }\end{array}$ \\
\hline 2015 & 0.788957 & 0.018344 & 0.027518 & 0.028374 & 0.030657 & 0.103417 & 0.002734 \\
\hline 2016 & 0.831843 & 0.013972 & 0.022417 & 0.022801 & 0.025994 & 0.080959 & 0.002014 \\
\hline 2017 & 0.865263 & 0.0105 & 0.018017 & 0.018075 & 0.021743 & 0.064939 & 0.001463 \\
\hline 2018 & 0.894543 & 0.007842 & 0.014392 & 0.014242 & 0.018077 & 0.049848 & 0.001057 \\
\hline 2019 & 0.91798 & 0.005814 & 0.011411 & 0.011139 & 0.014918 & 0.037981 & 0.000758 \\
\hline 2020 & 0.936512 & 0.004285 & 0.008995 & 0.008661 & 0.012239 & 0.028769 & 0.00054 \\
\hline
\end{tabular}


Table 20. Predicted values of the power needed per 10 thousand yuan (10 thousand kilowatt-hours).

\begin{tabular}{|c|c|c|c|c|c|c|c|}
\hline Year & $\begin{array}{l}\text { Coal-Mining and } \\
\text { Washing Industry }\end{array}$ & $\begin{array}{l}\text { Oil-Processing and } \\
\text { Coking Industry }\end{array}$ & $\begin{array}{l}\text { Chemical Raw Materials } \\
\text { Manufacturing Industry }\end{array}$ & $\begin{array}{c}\text { Ferrous Metal } \\
\text { Smelting Industry }\end{array}$ & $\begin{array}{c}\text { Non-Ferrous Metal Smelting } \\
\text { and Processing Industry }\end{array}$ & $\begin{array}{c}\text { Electric Power Production } \\
\text { and Supply Industry }\end{array}$ & $\begin{array}{c}\text { Construction } \\
\text { Industry } \\
\end{array}$ \\
\hline 2015 & 0.132404 & 0.012005 & 0.14954 & 0.19858 & 0.122863 & 0.347657 & 0.03695 \\
\hline 2016 & 0.120698 & 0.009116 & 0.148128 & 0.190924 & 0.111694 & 0.37698 & 0.042461 \\
\hline 2017 & 0.0996 & 0.006266 & 0.132825 & 0.166167 & 0.091918 & 0.459054 & 0.044169 \\
\hline 2018 & 0.089104 & 0.004669 & 0.129121 & 0.156786 & 0.082006 & 0.488503 & 0.049812 \\
\hline 2019 & 0.079252 & 0.003459 & 0.124793 & 0.147077 & 0.072739 & 0.516831 & 0.055849 \\
\hline 2020 & 0.070098 & 0.002548 & 0.119942 & 0.137205 & 0.064162 & 0.543772 & 0.062272 \\
\hline
\end{tabular}

Table 21. Predicted values of the total $\mathrm{CO}_{2}$ emissions per 10 thousand yuan (10 thousand tons).

\begin{tabular}{|c|c|c|c|c|c|c|c|}
\hline Year & $\begin{array}{l}\text { Coal-Mining and } \\
\text { Washing Industry }\end{array}$ & $\begin{array}{c}\text { Oil-Processing and } \\
\text { Coking Industry }\end{array}$ & $\begin{array}{l}\text { Chemical Raw Materials } \\
\text { Manufacturing Industry }\end{array}$ & $\begin{array}{c}\text { Ferrous Metal } \\
\text { Smelting Industry }\end{array}$ & $\begin{array}{c}\text { Non-Ferrous Metal Smelting } \\
\text { and Processing Industry }\end{array}$ & $\begin{array}{c}\text { Electric Power Production } \\
\text { and Supply Industry }\end{array}$ & $\begin{array}{c}\text { Construction } \\
\text { Industry } \\
\end{array}$ \\
\hline 2015 & 0.142249 & 0.029627 & 0.154097 & 0.183148 & 0.143705 & 0.307594 & 0.039579 \\
\hline 2016 & 0.137037 & 0.029403 & 0.15601 & 0.179434 & 0.139358 & 0.31071 & 0.048048 \\
\hline 2017 & 0.131716 & 0.029114 & 0.15759 & 0.175398 & 0.134836 & 0.313149 & 0.058196 \\
\hline 2018 & 0.126271 & 0.028753 & 0.158769 & 0.171004 & 0.13012 & 0.314779 & 0.070303 \\
\hline 2019 & 0.120684 & 0.02831 & 0.159472 & 0.166215 & 0.125187 & 0.31546 & 0.084671 \\
\hline 2020 & 0.11494 & 0.027777 & 0.159617 & 0.160994 & 0.12002 & 0.315033 & 0.101618 \\
\hline
\end{tabular}

Table 22. Optimization design of the seven largest industries in terms of carbon emissions in the secondary industry in Shanxi province (\%).

\begin{tabular}{|c|c|c|c|c|c|c|c|}
\hline Year & $\begin{array}{l}\text { Coal-Mining and } \\
\text { Washing Industry }\end{array}$ & $\begin{array}{l}\text { Oil-Processing and } \\
\text { Coking Industry }\end{array}$ & $\begin{array}{l}\text { Chemical-Raw-Materials } \\
\text { Manufacturing Industry }\end{array}$ & $\begin{array}{c}\text { Ferrous-Metal } \\
\text { Smelting Industry }\end{array}$ & $\begin{array}{c}\text { Non-Ferrous Metal Smelting } \\
\text { and Processing Industry }\end{array}$ & $\begin{array}{c}\text { Electric-Power-Production } \\
\text { and Supply Industry }\end{array}$ & $\begin{array}{c}\text { Construction } \\
\text { Industry } \\
\end{array}$ \\
\hline 2015 & 57.55 & 8.61 & 2.25 & 10.85 & 1.76 & 5.33 & 13.65 \\
\hline 2016 & 64.95 & 7.31 & 1.61 & 8.27 & 1.23 & 4.13 & 12.5 \\
\hline 2017 & 68.35 & 6.68 & 1.35 & 7.15 & 1.02 & 3.6 & 11.85 \\
\hline 2018 & 71.53 & 6.07 & 1.13 & 6.15 & 0.84 & 3.12 & 11.16 \\
\hline 2019 & 74.46 & 5.48 & 0.94 & 5.26 & 0.69 & 2.69 & 10.48 \\
\hline 2020 & 77.16 & 4.93 & 0.77 & 4.48 & 0.56 & 2.32 & 9.78 \\
\hline
\end{tabular}


In the structure optimization of the seven largest industries in terms of carbon emissions in the secondary industry, the GDP proportion of the output value of the coal-mining and washing industry increases steadily, which will support the development of coal-related industries such as coal liquefaction and coal gas in Shanxi province. The GDP proportions of the output value of the other six industries continue to decline, which are also consistent with the further development of the tertiary industry in Shanxi province.

\section{Conclusions}

Based on the statistical data from 2007 to 2011, the paper calculated the investment efficiency, energy efficiency and environment efficiency of the three industries and the coal-mining and washing industry, the oil processing and coking industry, the chemical raw materials manufacturing industry, the ferrous metal smelting industry, the non-ferrous metal smelting and processing industry, the electric power production and supply industry and the construction industry of Shanxi province. Then, the paper optimized the structure of the three industries and the seven largest industries in terms of carbon emissions in the secondary industry using the grey dynamic linear programming model in Shanxi province from 2015 to 2020 . The conclusions are as follows:

(1) Combining the advantages and disadvantages of the current situation regarding the energy industry development, Shanxi province may continue to develop coal resource and power industry in the adjustment of its industrial structure. However, clean mining should be a breakthrough to promote green production and technological innovation, low carbon development of coal and the related industries should be strongly promoted. (2) Shanxi province may vigorously develop its non-coal industry rather than sole resource oriented industry of coal. For example, Shanxi province may try to develop other industries such as finance and historical mining tourism rather than industries which are strongly reliant on the coal resources as chemical industry, etc.

\section{Acknowledgments}

The authors express their sincere thanks for the support from the National Natural Science Foundation of China under Grant No.71173200 and the support from the Development and Research Center of China Geological Survey under Grant No.1212011220302 and 12120114056601 , Key Laboratory of Carrying Capacity Assessment for Resource and Environment, Ministry of Land and Resources (Chinese Academy of Land and Resource Economics, China University of Geosciences Beijing) under Grant No.CCA2015.08.

\section{Author Contributions}

$\mathrm{Li} \mathrm{Li}$ and Yalin Lei designed the research and methodology; Xianhai Li, Li Li collected and compiled all the data and literature; $\mathrm{Li} \mathrm{Li}$ and Xianhai Li finished the experiment and calculation; Yalin Lei, Lianrong Zhao and Li Li analyzed the results and put forward the policies; Yalin Lei and Li Li revised the manuscripts and approved the manuscripts; Yalin Lei, Lianrong Zhao will responsible for the future questions from readers as the corresponding authors. 


\section{Conflicts of Interest}

The authors declare no conflict of interest.

\section{References}

1. Business Information Network, Analysis on the Reserves of Coal Resource in Shanxi Province, China. Available online: http://www.askci.com/news/201404/08/0816345137629.shtml (accessed on 8 August 2014).

2. Mao, D.; Duan, M.; Li, X.; Su, J.; Wang, Y. Selection of deepwater floating oil platform based on grey correlation. Pet. Explor. Dev. 2013, 40, 796-800.

3. Xiang, M.; Xu, Y.; Li, C.; Liu, Y.; Zhang, Y. Energy conservation co-operative control mechanism based on gray prediction for structural air compressor. Autom. Constr. 2013, 30, 184-190.

4. Wang, X.; Cai, Y.; Xu, Y.; Zhao, H.; Chen, J. Optimal strategies for carbon reduction at dual levels in China based on a hybrid nonlinear grey-prediction and quota-allocation model. J. Clean. Prod. 2014, 83, 185-193.

5. Liu, K.; Shen, X.; Tan, Z.; Guo, W. Grey clustering analysis method for overseas energy project investment risk decision. Syst. Eng. Procedia 2012, 3, 55-62.

6. Tai, Y.Y.; Lin, J.Y.; Chen, M.S.; Lin, M.C. A grey decision and prediction model for investment in the core competitiveness of product development. Technol. Forecast. Soc. Chang. 2011, 78, $1254-1267$.

7. Liu, Y.; Zhi, X.; Wang, S.; Gu, Z.; Zhu, X. Study of Gray Forecasting Optimal Control for the Vibration of a Rotor System. Mech. Sci. Technol. 2004, 1, 21-24.

8. Wang, R.; Tang, D. Study on Agriculture Industrial Structure Optimization of Liaoning Province Based on Gray System Theory. J. Agric. Mech. Res. 2007, 12, 5-8.

9. Zhu, Y.J.; Gao, X.Y. Grey Correlation and Grey Prediction Analysis on Forestry Industrial Structure of Heilongjiang Province. For. Eng. 2008, 6, 77-80.

10. The Secretary of State for Trade and Industry. Our Energy Future-Creating a Low Carbon Economy; The Stationary Office: London, UK, 2003.

11. Soytas, U.; Sari, R.; Ewing, B.T. Energy consumption, income, and carbon emissions in the United States. Ecol. Econ. 2007, 62, 482-489.

12. Zhang, Z.; Xue, Q. Low-carbon economy, industrial structure and changes in China's development mode based on the data of 1996-2009 in empirical analysis. Energy Procedia 2011, $5,2025-2029$.

13. Liu, C.; Duan, M.; Zhang, X.; Zhou, J.; Zhang, T.; Yang, G.; Ou, X.; Wang, E.; Dai, C.; Guo, S.; Hu, G.; Zhou, L.; Qi, T. Research on Causality Relationship of Low-Carbon Development and Industrial Structure. Procedia Environ. Sci. 2011, 11, 953-959.

14. Zhang, M.; Huang, X.J. Effects of industrial restructuring on carbon reduction: An analysis of Jiangsu Province, China. Energy 2012, 44, 515-526.

15. Dong, L.; Fujita, T.; Zhang, H.; Dai, M.; Fujii, M.; Ohnishi, S.; Geng, Y.; Liu, Z. Promoting low-carbon city through industrial symbiosis: A case in China by applying HPIMO model. Energy Policy 2013, 61, 864-873. 
16. Heston, S.L.; Rouwenhorst, K.G. Does industrial structure explain the benefits of international diversification? J. Financ. Econ. 1994, 36, 3-27.

17. Peneder, M. Industrial structure and aggregate growth. Struct. Chang. Econ. Dyn. 2003, 4, 427-448.

18. Zhang, J.F.; Deng, W.L. Industrial Structure Change and Its Eco-environmental Influence since the Establishment of Municipality in Chongqing, China. Procedia Environ. Sci. 2010, 2, 517-526.

19. Chivu, L.; Ciutacu, C. About industrial structures decomposition and recomposition. Procedia Econ. Financ. 2014, 8, 157-166.

20. Zhou, S.L. Discussion on rationalization and industry policy of the industrial structure in China. China Ind. Econ. 1987, 5, 12-22.

21. Wang, C.X.; Liu, D.R. Quantitative analysis model of the rationalization of industrial structure. Tech. Econ. 2002, 4, 51-53.

22. Ning, Y.L.; Xu, M.C. Discussing scientific development concept and optimization of the structure of Shanxi coal industry. North. Econ. 2006, 1, 63-64.

23. Qiao, X.C. Enhance the Quality of the Shanxi Coal Industrial Structure Based on the Industry. Master's Thesis, Guangxi University, Nanning, China, 2011.

24. Man, S.R.; Zhu, Q.C. Study on the relationship between industrial structure and economic growth in Yunnan-Based on grey correlation model. Econ. Res. Guide 2011, 35, 71-74.

25. Li, W.L. Optimization of Industrial Structure in Henan Province Based on Gray Dynamic Linear Programming. Master's Thesis, Zhengzhou University, Zhengzhou, China, 2012.

26. Li, Y.X.; Li, F.F.; Wang, R.Z. Evaluation the rationalization of industrial structure based on rough set theory-Taking Xinjiang production and Construction Corps as an example. Xinjiang Farming Cultiv. Econ. 2013, 6, 25-30.

27. Liu, S.F.; Dang, Y.G.; Fang, Z.G.; Xie, N.M. Grey System Theory and Its Application; Science Press: Beijing, China, 2010.

28. Tang, D.S.; Deng, M.J. Management of Water Rights in Tarim River Basin; Water Conservancy and Hydropower Press: Beijing, China, 2010.

29. Dang, Y.G.; Liu, S.F.; Wang, Q.F. The Theory and Practice of the Optimization of Regional Industrial Structure; Science Press: Beijing, China, 2011.

30. Statistical Bureau of Shanxi Province. Shanxi Statistical Yearbook 2008; China Statistical Press: Beijing, China, 2010.

31. Statistical Bureau of Shanxi Province. Shanxi Statistical Yearbook 2009; China Statistical Press: Beijing, China, 2011.

32. Statistical Bureau of Shanxi Province. Shanxi Statistical Yearbook 2010; China Statistical Press: Beijing, China, 2012.

33. Statistical Bureau of Shanxi Province. Shanxi Statistical Yearbook 2011; China Statistical Press: Beijing, China, 2013.

34. Statistical Bureau of Shanxi Province. Shanxi Statistical Yearbook 2012; China Statistical Press: Beijing, China, 2014.

(C) 2015 by the authors; licensee MDPI, Basel, Switzerland. This article is an open access article distributed under the terms and conditions of the Creative Commons Attribution license (http://creativecommons.org/licenses/by/4.0/). 